\title{
The Effect of Elastic Resistance Band Training on Postural Control and Body Composition in Sedentary Women*
}

\author{
Yağmur KOCAOĞLU ${ }^{\dagger 1}$, Nurtekin ERKMEN 1 (D \\ ${ }^{1}$ Faculty of Sport Sciences, Selçuk University, Konya, Turkey
}

Original Article

Received: 15.04 .2021
DOI:10.25307/jssr.917023

Accepted: 10.06.2021
Online Publishing: 30.06.2021

\begin{abstract}
This study aimed to analyze the effects of an 8-week training with the elastic resistance bands on body composition and postural control in sedentary women. Thirty-four female sedentary university students participated in the study based on voluntariness. The subjects were randomly divided into two groups: The experimental group and the control group. The experimental group performed an 8-week elastic resistance band training. Body composition measurements included the body weight, body mass index, body fat percentage, skinfold thicknesses, and circumferences. The Overall Stability Index and limit of stability were measured to evaluate postural performance using the Biodex Balance System. The overall stability index scores were evaluated for two conditions: Eye-open and eye-closed. After the training, body weight, the circumferences of waist, upper arm, and calf significantly increased $(\mathrm{p}<0.05)$ although there was no change in the circumferences of the hip, thigh, shoulder, and chest ( $>>0.05)$. The skinfold thicknesses and body fat percentage decreased in the experimental group $(\mathrm{p}<0.05)$. The training caused the overall stability index scores to reduce in eye-open and eye-closed conditions. There was no significant difference in the limit of stability scores ( $p>0.05$ ). In conclusion, these results show that elastic resistance band exercise could increase postural control and body composition in sedentary women. Also, the results suggest that the training might lower sedentary women's body fat by increasing muscle mass.
\end{abstract}

Keywords: Body Composition, Elastic Band Exercise, Female, Postural Sway.

\section{Sedanter Kadınlarda Elastik Direnç Bant Antrenmanlarının Postüral Kontrole ve Vücut Kompozisyonuna Etkisi}

$\ddot{\mathbf{O z}}$

Bu çalışma sedanter kadınlarda 8 haftalık elastik direnç bantları ile yapılan antrenmanın vücut kompozisyonu ve postüral kontrol üzerindeki etkilerini incelemeyi amaçlamıştır. Araştırmaya gönüllülük esasına göre üniversite öğrencisi olan 34 sedanter kadın katılmıştır. Katılımcılar rastgele iki gruba ayrılmıştır: Deney Grubu ve Kontrol Grubu. Deney grubu, 8 haftalık bir elastik direnç bant antrenmanına katılmışlardır. Vücut kompozisyonunu belirlemek için vücut ağırlığı, vücut kitle indeksi, vücut yağ yüzdesi, deri kıvrım kalınlıkları ve çevre ölçümleri gerçekleştirildi. Postüral kontrolü değerlendirmek için Biodex Denge Sistemi kullanılarak genel stabilite indeksi ve stabilite sınırları ölçülmüştür. Genel stabilite indeksi skorları iki koşulda değerlendirilmiştir: Göz açık ve göz kapalı. Antrenman sonrası vücut ağırlığı, bel, üst kol ve baldır çevresi önemli ölçüde $\operatorname{artmıştır~}(p<0,05)$, ancak kalça, uyluk, omuz ve göğüs çevresinde değişiklik gözlemlenmedi $(p>0,05)$. Deney grubunda deri kıvrım kalınlıkları ve vücut yă̆ yüzdesi azaldı $(\mathrm{p}<0,05)$. Elastik direnç bant antrenmanı, gözler açık ve gözler kapalı koşullarda genel stabilite indeksi puanlarının düşmesine neden oldu. Sanılım sınırları skorlarında anlamlı bir farklılık yoktu $(\mathrm{p}>0,05)$. Bu sonuçlar, elastik direnç bant antrenmanlarının sedanter kadınların postüral kontrolünü ve vücut kompozisyonunu artırabileceğini göstermektedir. Ayrıca sonuçlar, elastik direnç bantları ile uygulanan antrenmanların kas kütlesini artırarak sedanter kadınların vücut yağ yüzdesini azaltabileceğini göstermiştir.

Anahtar Kelimeler: Elastik Bant Egzersizleri, Kadın, Postüral Salınım, Vücut Kompozisyonu.

*The paper is a part of Kocaoglu's master thesis. It was supported financially by the Coordinator of Scientific Researches Projects (BAP) at Selcuk University (Project Number: 14202008).

Corresponding Author: Yağmur KOCAOĞLU, E-mail: ygmrkocaoglu@gmail.com 


\section{INTRODUCTION}

The postural control, namely, balance capacity, which is described as keeping body weight center and having postural sway against gravity changes during physical activities and rest (Kitamura \& Matsunaga, 1990) and is a prerequisite for most sport branches, has great importance in daily life as well (Marion \& Tony, 1997). It is necessary to follow an appropriate position and keep a balanced posture during body movements (Aydin, Yildiz, Yildiz, Atesalp, \& Kalyon, 2002). For postural control, three sensory systems including visual, auditory, and proprioceptive ones are required. To combine these sensory systems in the brain and have enough motor response, it is also necessary to combine afferent information from the vestibular apparatus in the inner ear and eyes with proprioceptive data from the periphery. For adequate motor responses, there must be a healthy neuromuscular system and efficient muscle strength. Postural control means a complex process involving interactions between these systems (Shumway-Cook \& Woollacott, 2001; Teasdale, Bard, LaRue, \& Fleury, 1993). Balance, which is one of the motor function components, is provided by the connection between these systems, and it is stated that the balance will be negatively affected if one of them is insufficient (McLeod \& Hansen, 1989).

Resistance training programs represent benefits such as recovering metabolism after fatigue due to daily chores as well as providing a healthy and long life for sedentary individuals, reducing the period for rest, increasing metabolic rate, providing bone mineral density, and reducing pain (Fisher, Steele, Bruce-Low, \& Smith, 2011). Resistance (strength) workouts are considered to be an inevitable part of exercise programs in achieving these objectives (ACSM, 2002).

Using weight lifting machines requires facilities and financial resources. The discussion on how to get these machines by people or how ideal is using weight lifting machines at home concerning their usage opportunities is still going on (Colado \& Triplett, 2008). In contrast to weight lifting machines, elastic resistance tools such as elastic bands are increasingly used more and more to develop muscular conditions because they are more economical, more accessible, and always applicable (Hostler et al., 2001). Elastic resistance bands, which allow exercises with concentric and eccentric contractions to be conducted in larger movement intervals, (Patterson, Stegink Jansen, Hogan, \& Nassif, 2001) also allow exercises to be done in more securable and controlled ways by changing width and rigidity (resistance level) for low or highly intensive efforts (Kraemer et al., 2001).

As one of the resistance workouts, elastic bands are exercise equipment that is now used in training practices of various sport branches as well as individual exercise practices and rehabilitation. Elastic bands are preferred because they are elastic, light, low-cost, easily portable, and clearable (Baltaci, Ergur, \& Bayrakci Tunay, 2016). Elastic bands are preferred because they are elastic, lightweight, low cost, easy to carry and clean (Baltac1 et al., 2003, Buscher et al., 2006) and they provide the opportunity to adjust the individual force and traction ratio (Baltaci et al., 2003). These bands, which are used as an aid to fitness and physical therapy, have varying resistance properties and each color indicates a different amount of resistance (Thera-Band, 2006). It can be used to strengthen muscle groups such as rotator cuff and peroneus longus, where weight lifting machines are not effective enough, and at the same time allows exercises that improve flexibility and balance (Page \& Ellenbecker, 2011). 
In many studies, the effects of workouts with elastic resistance bands were analyzed but they were mostly applied in middle and older age groups for rehabilitation (Colado et al., 2012; Colado \& Triplett, 2008; Egana, Reilly, \& Green, 2010; Han, Ricard, \& Fellingham, 2009). There are limited studies on the effects of elastic resistance training on postural sway. To live a better quality of life, scientific data are needed to show that maintaining strength gain at younger ages and resistance training can reduce loss of balance. In this study, we hypothesized that training applied with elastic resistance bands would improve postural sway and body composition. Thus, this study aimed to analyze the effects of an 8-week training with the elastic resistance bands on body composition and postural control in sedentary females.

\section{METHOD}

\section{Participants}

In this study, the pre-test/post-test control group design was used. Thirty-four sedentary female university students volunteered to participate in this study (age: $21.88 \pm 1.63$ years; height: $161.50 \pm 5.48 \mathrm{~cm}$ and body weight: $59.35 \pm 7.90 \mathrm{~kg}$ ). They had no resistance training experience. Before the study, the subjects were randomly divided into two groups: the experimental group (EG, $n=17)$ and the control group $(C G, n=17)$. The subjects reported that they did not have any lower extremity injuries and/or neurological diseases before. Before the study, all participants were informed about the study, the risks they could encounter were explained, and a signed consent form was obtained from all participants.

The subjects' body weights and heights were measured with a stadiometer (Seca 700 Physician's Scale) before the measurements. Body mass index (BMI) was calculated using the formula: BMI $=$ Weight $(\mathrm{kg}) /$ Height $\left(\mathrm{m}^{2}\right)$. The subjects' skinfold thicknesses was obtained from 7 separate regions (biceps, triceps, subscapular, suprailiac, chest, thigh, abdominal) with Holtain Skinfold Caliper. All measurements were taken from the right part of the body and twice for each region. Their body densities were determined with the Durnin-Womersley formula, the subjects' body fat percentages (BF\%) were estimated with the Siri Formula (Durnin \& Womersley, 1974; Siri, 1956).

Durnin Womersley Formula $=1.1468-0.074 * \log ($ triceps skinfold + subscapular skinfold $)$. Siri Formula $=(4.95 /$ body density -4.5$) * 100$.

The circumference measurements were taken from 7 separate regions including waist, hip, upper arm, thigh, shoulder, and chest and calf circumferences when standing, given weight on both feet and in balance, with anatomic positions, by using a tape measure.

\section{Postural Sway Measurements}

Biodex Balance System (BBS, Biodex Medical Systems Inc, Shirley, NY) was used to measure the subjects' postural sway. In many studies, it was denoted that the BBS is a reliable tool to measure and record the subjects' skills to keep their postures under dynamic stress (Arnold \& Schmitz, 1998; Cachupe, Shifflett, Kahanov, \& Wughalter, 2001). Eyes-open (EO) and eyesclosed (EC) postural sway tests were conducted on the dominant leg, the resistance level of the BBS was adjusted as "level 8" in EO condition, as "static level" in EC condition. Each postural 
sway test in EO condition and EC condition lasted $20 \mathrm{sec}$. Tests started after the subject used visual information from the screen of the BBS and arranged her gravity center. In the EO condition, the screen of the BBS was closed during tests, and the subjects were asked to look at the point at eye level about $1 \mathrm{~m}$ ahead of the subjects. In the EC condition, the subjects' eyes were closed during tests. The subjects were required to keep their position for $20 \mathrm{sec}$. After the test, the BBS calculated an Overall Stability Index (OSI) score representing the subjects' postural performance. The OSI scores were recorded for each subject in the EO and the EC conditions separately.

In the Limit of Stability (LOS) test, the resistance level of the BBS was adjusted as "level 8". The subjects were positioned with both feet on the ground and crossed arms on shoulders. In this position, the subject used feedback from the track of her gravity center on the screen, placed her feet in the most stable position. When the subjects were positioned with EO and on pair feet for the test, they completed the test following the user manual of the BBS. The test required them to move the subject-controlled platform towards their tracks on the screen and to move the gravity center of the body towards the track. The test was run against time, and the time to complete the test indicates the subject's test score.

\section{Elastic Resistance Band Training}

In a week before elastic resistance band (ERB) training, the subjects were shown the features of elastic bands and the practice styles of movements to be done, required for getting accustomed to training and being ready. Since the right breathing technique is a basic factor for resistance workouts during the movements, it was emphasized that they breathe out when extending band length, breath in when shrinking band length (turning into the first stage) (Page \& Ellenbecker, 2019).

The accepted standards were taken into account in the preparation of the training program (Page \& Ellenbecker, 2019). During elastic resistance band exercises, the subjects in the EG used red elastic bands for the first 3 weeks, blue ones for the next 3 weeks, and silver ones for the last two weeks (Thera-Band, the Hygenic Corporation, Akron OH, USA), did exercises for three times per week during 8 weeks, with $100 \%$ tension for each band color. Exercises were applied as 3 sets, 10-15 repetitions, resting period of 30 seconds between sets, and 15 seconds between movements. A total of 60 minutes including 10 minutes of warm-up, 40 minutes of exercise, and 10 minutes of cool-down was arranged as exercise.

Six exercises were used for the upper extremity, 5 for the lower extremity, and 4 exercises for trunk muscles. The training program consisted of 15 exercises including lateral raise (deltoid), side bend (oblique abdominals), glute combo kickback (gluteus maximus), seated row (latissimus dorsi), back extensions (lower back), leg abduction (gluteus medius), chest press (pectoralis major), double leg press (rectus abdominals), squat (gluteus maximus, quadriceps), overhead press (deltoid, upper trapezius), leg raise (rectus abdominals), leg curl (hamstring), triceps curl (triceps), plantar flexion (gastrocnemius, soleus), biceps curl (biceps) respectively.

\section{Ethical Approval}

The study was approved by the local ethical committee (Selcuk University Physical Education and Sports School Ethics Committee: 2014/003). 


\section{Statistical Analysis}

Descriptive statistics using the mean and standard deviation were applied. The normality distribution was examined with Shapiro-Wilk Test. According to the Normality tests results, Unpaired t-test or Mann Whitney U test for the independent groups, Paired Samples t-test or Wilcoxon $\mathrm{Z}$ test for the dependent groups were utilized. SPSS for Windows 22.0 package program was used in the statistical analyses of data. The significance level was set at 0.05 .

\section{RESULTS}

The mean age was $21.82 \pm 1.91$ years for the EG and $21.94 \pm 1.34$ years for the CG. The mean height was $161.68 \pm 6.02 \mathrm{~cm}$ for the EG and $161.32 \pm 5.07 \mathrm{~cm}$ for the CG. There is no significant difference in subjects' age $(t=-0.208 ; \mathrm{p}>0.05)$ and height $(\mathrm{t}=0.188 ; \mathrm{p}>0.05)$ between EG and CG.

Table 1. Skinfold thicknesses and BF\% in pretest and posttest of the EG and CG

\begin{tabular}{|c|c|c|c|c|}
\hline Variables & Groups & Pre-Test & Post-Test & Mean Difference \\
\hline \multirow{2}{*}{ Body Weight (kg) } & EG & $62.92 \pm 8.81^{\mathrm{b}}$ & $63.67 \pm 9.02^{\mathrm{ab}}$ & $-0.75 \pm 0.91$ \\
\hline & $\mathrm{CG}$ & $56.01 \pm 5.25$ & $56.40 \pm 5.52$ & $-0.39 \pm 0.92$ \\
\hline \multirow{2}{*}{ BMI $\left(\mathbf{k g} / \mathbf{m}^{2}\right)$} & EG & $23.81 \pm 2.78$ & $24.14 \pm 3.07^{b}$ & $-0.33 \pm 0.98$ \\
\hline & $\mathrm{CG}$ & $21.91 \pm 3.09$ & $21.81 \pm 2.79$ & $0.09 \pm 0.73$ \\
\hline \multirow{2}{*}{ Biceps (mm) } & EG & $10.13 \pm 3.02$ & $7.48 \pm 2.31^{\mathrm{a}}$ & $2.64 \pm 1.61^{\mathrm{b}}$ \\
\hline & $\mathrm{CG}$ & $8.75 \pm 4.40$ & $8.55 \pm 3.77$ & $0.19 \pm 1.77$ \\
\hline \multirow{2}{*}{ Triceps (mm) } & EG & $20.03 \pm 4.06$ & $17.46 \pm 4.08^{\mathrm{a}}$ & $2.56 \pm 1.78^{\mathrm{b}}$ \\
\hline & $\mathrm{CG}$ & $18.01 \pm 4.50$ & $18.03 \pm 4.59$ & $-0.02 \pm 0.98$ \\
\hline \multirow{2}{*}{ Subscapular (mm) } & EG & $13.18 \pm 3.70$ & $12.89 \pm 3.56^{\mathrm{a}}$ & $0.29 \pm 0.39$ \\
\hline & $\mathrm{CG}$ & $11.24 \pm 5.06$ & $11.08 \pm 4.82$ & $0.16 \pm 1.11$ \\
\hline \multirow{2}{*}{ Suprailliac (mm) } & EG & $15.33 \pm 5.13$ & $13.05 \pm 3.84^{\mathrm{a}}$ & $2.28 \pm 2.67^{\mathrm{b}}$ \\
\hline & $\mathrm{CG}$ & $15.38 \pm 6.05$ & $15.23 \pm 5.62$ & $0.14 \pm 1.65$ \\
\hline \multirow{2}{*}{ Chest (mm) } & EG & $11.95 \pm 6.03$ & $8.94 \pm 4.16^{\mathrm{a}}$ & $3.02 \pm 2.68^{\mathrm{b}}$ \\
\hline & CG & $9.73 \pm 6.01$ & $8.90 \pm 4.81$ & $0.83 \pm 2.83$ \\
\hline \multirow{2}{*}{ Thigh (mm) } & EG & $33.69 \pm 5.76$ & $30.76 \pm 6.18^{\mathrm{a}}$ & $2.93 \pm 2.98^{b}$ \\
\hline & $\mathrm{CG}$ & $31.56 \pm 8.32$ & $31.26 \pm 8.10$ & $0.31 \pm 1.12$ \\
\hline \multirow{2}{*}{ Abdominal (mm) } & EG & $23.19 \pm 5.74$ & $20.22 \pm 5.50^{\mathrm{a}}$ & $2.97 \pm 2.86^{\mathrm{b}}$ \\
\hline & CG & $21.88 \pm 8.00$ & $21.93 \pm 8.09$ & $-0.05 \pm 1.82$ \\
\hline \multirow{2}{*}{ BF\% } & EG & $28.13 \pm 2.90$ & $26.76 \pm 3.03^{\mathrm{a}}$ & $1.37 \pm 1.06^{\mathrm{b}}$ \\
\hline & CG & $26.10 \pm 4.72$ & $26.03 \pm 4.71$ & $0.07 \pm 0.69$ \\
\hline
\end{tabular}

${ }^{a}$ Significant difference between pre and post-test $(\mathrm{p}<0.05)$.

${ }^{\mathrm{b}}$ Significant difference between the EG and the CG $(\mathrm{p}<0.05)$.

Table 1 shows the subjects' skinfold thicknesses $(\mathrm{mm})$ and BF\%. Before the training, the EG had a higher body weight than $\mathrm{CG}(\mathrm{t}=2.675 ; \mathrm{p}<0.05)$. Similarly, the bodyweight of the EG was higher than $\mathrm{CG}(\mathrm{t}=2.727 ; \mathrm{p}<0.05)$ after the training. Bodyweight in the EG significantly increased $(\mathrm{t}=-3.161 ; \mathrm{p}<0.05)$ after the training. No statistically significant difference in body weight was found between pre-and post-tests in the CG $(t=-1,708 ; p>0.05)$. There was no significant difference between the EG and the CG in the bodyweight pre-test and post-test differences $(t=-1.069 ; p>0.05)$. 
There were no statistically significant differences between the pre-tests of the EG and the CG in skinfold thicknesses and BF\% $(t=1.043 ; p>0.05$ for biceps, $t=1.301 ; p>0.05$ for triceps, $\mathrm{t}=1.276 ; \mathrm{p}>0.05$ for subscapular, $\mathrm{t}=-0.021 ; \mathrm{p}>0.05$ for suprailliac, $\mathrm{U}=94.500 ; \mathrm{p}>0.05$ for chest, $\mathrm{t}=0.868 ; \mathrm{p}>0.05$ for thigh, $\mathrm{t}=0.514 ; \mathrm{p}>0.05$ for abdominal, and $\mathrm{t}=1.402 ; \mathrm{p}>$ 0.05 for $\mathrm{BF} \%)$. After the training period, no significant difference between the post-tests was found in the skinfold thicknesses of biceps $(\mathrm{t}=-0.977 ; \mathrm{p}>0.05)$, triceps $(\mathrm{t}=-0.358 ; \mathrm{p}>0.05)$, subscapular $(\mathrm{t}=1.251 ; \mathrm{p}>0.05)$, suprailiac $(\mathrm{t}=-1.250 ; \mathrm{p}>0.05)$, chest $(\mathrm{U}=113.500 ; \mathrm{p}>$ $0.05)$, thigh $(\mathrm{t}=-0.200 ; \mathrm{p}>0.05)$, abdominal $(\mathrm{t}=-0.675 ; \mathrm{p}>0.05)$, and $\mathrm{BF} \%(\mathrm{t}=0.500 ; \mathrm{p}>$ $0.05)$.

On the other hand, the training in the EG caused significantly decreases in the skinfold thicknesses of biceps $(t=6.555 ; \mathrm{p}<0.05)$, triceps $(\mathrm{t}=5.387$; $\mathrm{p}<0.05)$, subscapular $(\mathrm{t}=3.057$; $\mathrm{p}<0.05)$, suprailliac $(\mathrm{t}=3.304 ; \mathrm{p}<0.05)$, chest $(\mathrm{Z}=-3.576 ; \mathrm{p}<0.05)$, thigh $(\mathrm{t}=4.060 ; \mathrm{p}<$ $0.05)$, and abdominal $(\mathrm{t}=4.016 ; \mathrm{p}<0.05)$ and BF\% $(\mathrm{t}=4.813 ; \mathrm{p}<0.05)$. There were not statistically significant difference between the pre- and post-tests in the biceps $(t=0.453)$, triceps $(\mathrm{t}=-0.099)$, subscapular $(\mathrm{t}=0.614)$, suprailliac $(\mathrm{t}=0.348)$, chest $(\mathrm{t}=1.131)$, thigh $(\mathrm{t}=$ 1.127), abdominal $(\mathrm{t}=-0.099)$ skinfold thickness and BF\% $(\mathrm{t}=0.420)$ of the $\mathrm{CG}(\mathrm{p}>0.05)$.

The mean differences between the pre- and post-tests in the BF\% (U = 27.000) and the skinfold thicknesses of biceps $(\mathrm{U}=17.500 ; \mathrm{p}<0.05)$, triceps $(\mathrm{t}=4.864 ; \mathrm{p}<0.05)$, suprailiac $(\mathrm{t}=2.697$; $\mathrm{p}<0.05)$, chest $(\mathrm{U}=32.000 ; \mathrm{p}<0.05)$, thigh $(\mathrm{U}=32.00 ; \mathrm{p}<0.05)$, abdominal $(\mathrm{U}=19.000 ; \mathrm{p}$ $<0.05)$ were significantly higher in the EG than $\mathrm{CG}(\mathrm{p}<0.05)$. But, when the mean differences between the pre- and post-tests were compared, subscapular skinfold thickness did not differ between the EG and CG $(\mathrm{U}=92.500 ; \mathrm{p}>0.05)$.

Table 2. The circumference measurements in pre-test and post-test of the EG and CG

\begin{tabular}{llccc}
\hline Variables & Groups & Pre-Test & Post-Test & Mean Difference \\
\hline \multirow{2}{*}{ Waist $(\mathbf{c m})$} & EG & $75.47 \pm 7.58$ & $76.65 \pm 7.59^{\mathrm{a}}$ & $-1.18 \pm 1.67^{\mathrm{b}}$ \\
& CG & $72.47 \pm 5.72$ & $72.38 \pm 5.23$ & $0.09 \pm 1.83$ \\
Hip $(\mathbf{c m})$ & EG & $101.0 \pm 10.13$ & $102.0 \pm 9.28$ & $-1.00 \pm 2.61^{\mathrm{b}}$ \\
& CG & $98.03 \pm 5.71$ & $97.68 \pm 5.30$ & $0.35 \pm 1.41$ \\
Upper arm (cm) & EG & $28.06 \pm 3.19$ & $28.88 \pm 3.24^{\mathrm{a}}$ & $-0.82 \pm 0.86^{\mathrm{b}}$ \\
& CG & $27.29 \pm 2.61$ & $27.09 \pm 2.58$ & $0.21 \pm 0.71$ \\
Thigh $(\mathbf{c m})$ & EG & $56.90 \pm 4.90$ & $57.83 \pm 5.45^{\mathrm{b}}$ & $-0.93 \pm 2.21$ \\
& CG & $53.68 \pm 5.88$ & $53.44 \pm 5.39$ & $0.24 \pm 1.71$ \\
Shoulder $(\mathbf{c m})$ & EG & $93.75 \pm 3.44$ & $94.22 \pm 4.35$ & $-0.47 \pm 1.48$ \\
& CG & $93.53 \pm 4.51$ & $93.13 \pm 3.50$ & $0.41 \pm 2.15$ \\
Chest $(\mathbf{c m})$ & EG & $90.94 \pm 4.88$ & $90.56 \pm 5.41$ & $0.38 \pm 1.38$ \\
\multirow{2}{*}{ Calf $(\mathbf{c m})$} & CG & $88.26 \pm 4.43$ & $88.21 \pm 3.81$ & $0.06 \pm 1.98$ \\
& EG & $36.50 \pm 3.57$ & $37.32 \pm 3.41^{\mathrm{ab}}$ & $-0.82 \pm 0.66^{\mathrm{b}}$ \\
\hline
\end{tabular}

${ }^{a}$ Significant difference between pre and post-test $(\mathrm{p}<0.05)$.

${ }^{\mathrm{b}}$ Significant difference between the EG and the CG ( $\left.\mathrm{p}<0.05\right)$.

When the pre-test circumference measurements before the training period were compared (Table 2), no statistically significant difference was found in pre-test values of waist $(\mathrm{U}=$ 121.000), hip $(\mathrm{t}=1.046)$, upper arm $(\mathrm{t}=.765)$, thigh $(\mathrm{t}=1.672)$, shoulder $(\mathrm{t}=.154)$, chest $(\mathrm{t}=$ $1.650)$ and calf $(t=1.291)$ between the $E G$ and the $C G$. When the post-test measurement were 
compared, the circumferences of the thigh $(\mathrm{t}=2.290)$ and the calf $(\mathrm{t}=2.180)$ were significantly higher in the EG than the $C G$ although the circumferences of the waist $(U=106.000)$, the hip $(\mathrm{t}=1.656)$, the upper $\operatorname{arm}(\mathrm{t}=1.788)$, the shoulder $(\mathrm{t}=.783)$ and the chest $(\mathrm{t}=1.454)$ were not different between the groups.

The training caused significant increases in the waist $(\mathrm{Z}=-2.544 ; \mathrm{p}<0.05)$, the upper arm $(\mathrm{t}=$ -3.926; $\mathrm{p}<0.05)$ and the calf $(\mathrm{t}=-5.144 ; \mathrm{p}<0.05)$ of the EG but not in the hip $(\mathrm{t}=-1.530)$, the thigh $(\mathrm{t}=-1.635)$, the shoulder $(\mathrm{t}=-1.269)$ and the chest $(\mathrm{t}=1.083)$. In the CG, no statistically significant difference was found between the pre-and post-test in the circumference measurements $(\mathrm{Z}=-.410$ for waist $\mathrm{t}=1.031$ for hip; $\mathrm{t}=1.198$ for upper $\operatorname{arm} ; \mathrm{t}=.566$ for thigh; $\mathrm{t}=.754$ for shoulder; $\mathrm{t}=.122$ for chest $\mathrm{t}=.320$ for calf).

When the mean differences between the pre-test and post-test were compared, the EG had significantly higher scores in the waist $(\mathrm{U}=83.500)$, the hip $(\mathrm{U}=79.000)$, the upper arm $(\mathrm{U}=$ 49.500), and the calf $(\mathrm{U}=42.500)$ than the $\mathrm{CG}$ but there was no significant difference for the thigh $(U=94.500)$, the shoulder $(U=104.00)$ and the chest $(U=99.000)$ between the groups.

Table 3 showed the OSI scores for the EO and EC conditions and LOS in the pre-test and the post-test. In the pre-tests, the OSI and LOS scores did not differ between the EG and CG (U = 90.500 for the OSI in EO condition; $\mathrm{p}>0.05, \mathrm{U}=76.500$ for the OSI in EC condition; $\mathrm{p}>$ $0.05, \mathrm{U}=95.000$ for LOS; $\mathrm{p}>0.05)$. In other words, the postural sway scores of the groups were similar before the training. After the training, the OSI score in the EC condition was significantly lower in the EG than the $\mathrm{CG}(\mathrm{U}=37.000 ; \mathrm{p}<0.05)$. In the posttest, the OSI in EO condition $(U=65.000 ; p>0.05)$ and $\operatorname{LOS}(U=85.500 ; p>0.05)$ were not different between the EG and CG.

Table 3. The OSI scores and LOS according to the groups

\begin{tabular}{lcccc}
\hline Variables & Groups & Pre-Test & Post-Test & Mean Difference \\
\hline OSI in EO & EG & $2.54 \pm 1.22$ & $1.48 \pm 0.64^{\mathrm{a}}$ & $1.06 \pm 1.15^{\mathrm{b}}$ \\
& CG & $2.09 \pm 0.91$ & $1.95 \pm 0.71$ & $0.13 \pm 0.61$ \\
OSI in EC & EG & $2.56 \pm 0.65$ & $2.06 \pm 0.59^{\mathrm{a} .} \mathrm{b}$ & $0.51 \pm 0.2^{\mathrm{b}}$ \\
& CG & $2.96 \pm 0.70$ & $3.05 \pm 0.95$ & $-0.09 \pm 0.87$ \\
LOS (sn) & EG & $56.81 \pm 11.58$ & $48.94 \pm 7.86^{\mathrm{a}}$ & $7.88 \pm 6.67$ \\
& CG & $62.31 \pm 13.70$ & $55.38 \pm 10.90$ & $6.94 \pm 13.14$ \\
\hline
\end{tabular}

${ }^{a}$ Significant difference between pre and post-test $(\mathrm{p}<0.05)$.

${ }^{\mathrm{b}}$ Significant difference between the EG and the CG $(\mathrm{p}<0.05)$.

For the EG, the elastic resistance training significantly decreased the OSI scores in EO condition $(Z=-2.984)$ and the OSI scores in EC condition $(Z=-1.994 ; p<0.05)$ and LOS $(Z$ $=-3.215)$. There were no significant differences in the OSI scores in the EO condition $(Z=-$ $.393)$ and the OSI scores in the EC condition $(Z=-.256)$ and LOS $(Z-1.735)$ between the preand post-tests of the CG.

When the mean differences between the pre-test and post-test were compared, the EG had significantly higher OSI scores in the EO condition $(\mathrm{U}=51.500)$ and EC condition $(\mathrm{U}=$ 79.500) than the CG. The mean differences of the LOS between the pre-and post-tests were not different between the EG and the $\mathrm{CG}(\mathrm{U}=118.500 ; \mathrm{p}>0.05)$. 


\section{DISCUSSION}

Many researchers analyzed the effects of workouts with the elastic resistance bands but they were mostly applied in middle and older age groups for rehabilitation (Colado et al., 2012; Colado \& Triplett, 2008; Egana et al., 2010; Han et al., 2009). The recent study examined the effects of an 8-week ERB training on body composition and postural performance in sedentary women. The study was carried out using elastic bands with different levels of resistance. The used resistance level during the training period was increased 2 times.

The results of the study suggested that the ERB training increased body weight by $0.75 \mathrm{~kg}$ although BMI did not change after the training. It could be said that BMI could be affected by 8 -week elastic resistance band exercises although it may increase muscle mass in sedentary women.

In the study, skinfold thicknesses from 7 regions were measured and calculated BF\%. All of the skinfold thicknesses decreased after the ERB training. In parallel with these results, the $\mathrm{BF} \%$ of the women reduced after 8 weeks. These results reveal that resistance training using an elastic band might be beneficial to lower BF\% of sedentary women.

Using elastic resistance training, a decrease in body fat occurs and fat-free mass increases (Colado, Triplett, Tella, Saucedo \& Abellán, 2009; Egana et al., 2010) similar to the training with weight lifting machines (Colado \& Triplett, 2008). Percentage change in body fat has a positive relationship with total cholesterol and a negative relationship with HDL cholesterol (Prabhakaran, Dowling, Branch, Swain \& Leutholtz, 1999). This relationship indicates that a decrease in body fat might enhance lipid profiles. Prabhakaran et al., (1999) showed that body fat could be reduced by using resistance training in sedentary premenopausal women. The study approves Prabhakaran et al., (1999) because sedentary women's body fat decreased after the elastic band training in the present study.

Some studies found that elastic band training did not affect body composition. LeCheminant et al., (2014) in healthy women after birth and Rogers, Sherwood, Rogers \& Bohlken (2002) in old females did not find any change in body composition after the elastic band training.

In parallel with these results of the study, ERB training may be referred to as the cause of increases in fat-free body mass and reduces body fat percentage. Different results were observed in the literature. Due to the analysis of individuals from different age categories, applying various training periods and weekly training numbers, presenting different elastic band resistance levels and overload intensity, no consensus was achieved with results.

The study found increases in the waist, hip, upper arm, and calf circumference following resistance band training although there was no change in the femur, shoulder, and chest circumference. These results might be due to hypertrophy in the muscles. Skeletal muscle can expand (hypertrophy) when exposed to stress that requires more force production. An increase in muscle size means adaptation to the training being performed (Ratamess, 2012). 
Although it was reported that resistance band exercise after birth did not cause any change in body composition of women (LeCheminant et al., 2014), it is suggested that it may cause a decrease in waist circumference of postmenopausal women (Colado et al., 2009). According to Lubans, Sheaman \& Callister (2010), both free weight exercises and elastic resistance bands exercises in adolescent girls increased fat-free body mass but no significant differences in waist circumference were observed. Kwon et al., (2010) noted that there were increases in upper body, body, and total body muscle mass but no differences in lower body muscle mass in females aged 45-65.

In literature, studies on the effects of ERB training on body circumference measurements were not available. Previous studies reported that elastic resistance workouts presented decreases (Colado et al., 2009) or no changes in waist circumference (Lubans et al., 2010), or no effects on body composition (LeCheminant et al., 2014). When considering these results of this study; sedentary women's skinfold thickness and body fat percentage reduced, body weight and BMI did not vary, resistance band exercises increased fat-free body mass, hereby, and some circumference measurements were subjected to increases. In this study, the mean age of the EG was 21.82 years and the mean BMI was $23.81 \mathrm{~kg} / \mathrm{m}^{2}$. It is known that the loss of muscle mass starts at the age of 30-40, continues as the age progresses, and the rate of body fat increases as the opposite of this situation. That's why elderly individuals having the same BMI had more body fat rate than young people (Rakıcıoglu, 2012). Previous studies focused on middle-aged or elderly women or overweight or obese women. The results varied from other studies, this one may result from the age and BMI averages of the participant subjects.

When evaluating the effects of the ERB training on balance performance; postural sway in eyes-open and eyes-closed conditions and LOS scores reduced after exercises. That is, the sedentary women showed improvements in their postural control performance. In parallel with these results, Han et al., (2009) informed that balance performance developed in females and males after 4-week of elastic resistance exercises. This development went on for 4 weeks after giving up exercises as well.

It is said that long-term elastic resistance training improves the ability to maintain a balanced position in the elderly (Holviala et al., 2014; Kılınç et al., 2014). According to Baker, Webright \& Perrin (1998) and Kaminski (2002), regular physical activity performed 3 times a week with elastic bands has a positive effect on postural sway.

In daily life, it is necessary to maintain and control posture and balance to be able to do things efficiently and to protect from accidents. In other words, balance is the basis for physical activity (Erkmen, Suveren, Göktepe \& Yazıcıŏlu, 2007). A high level of muscular activation is observed during resistance exercises with elastic bands (Andersen et al., 2010; Jakobsen, Sundstrup, Andersen, Aagaard \& Andersen, 2013). Lower and upper body strength affect balance in females and males and resistance training is highly effective on balance development (LeMura et al., 2000). Quadriceps muscular strength is the most important factor which affects balance (Ünlüsoy et al., 2011).

Muscular strength can be increased by elastic resistance training (Rogers et al., 2002). The increase in muscle strength affects postural control parameters positively. Looking at the results 
of this study, sedentary women's postural sway scores decreased as expected after an 8-week ERB training. These results support that balance development is based on increasing muscle strength after training.

\section{CONCLUSIONS}

As a result, the ERB training enhanced postural performance, reduced the skinfold thickness and BF\% although BMI did not change in sedentary women. The training increased circumferences of waist, upper arm, and calf did not affect the circumferences of hip, shoulder, thigh, and chest. These results show that elastic resistance band exercise could increase postural control and body composition in sedentary women. Also, the results suggest that the training might lower sedentary women's body fat by increasing muscle mass. To better understand the effect of ERB training on the circumference, body fat percentage, and skinfold thickness, studies involving longer training periods are needed. In addition, future study may examine muscular development and postural sway through resistance training.

Funding: The paper is a part of Kocaoglu's master thesis. It was supported financially by the Coordinator of Scientific Researches Projects (BAP) at Selcuk University (Project Number: 14202008).

Conflict of Interest Statement: The authors have no conflicts of interest that are directly relevant to the content of this study.

Author Contribution: This study has been researched and concluded in accordance with scientific and ethical rules; We also declare that we are responsible for the entire study from the creation, design, data collection and processing, analysis and interpretation of the study idea. Study Design-YK; NE, Data Collection-YK, Statistical Analysis-YK; NE, Manuscript Preparation-YK.

\section{Research Ethic}

Ethics Committee:Selcuk University Physical Education and Sports School Ethics

Committee

Date: 14.02 .2014

Decision / Protocol number : 2014 / 003 


\section{REFERENCES}

ACSM. (2002). Progression models in resistance training for healthy adults. Med Sci Sports Exerc, 34(2), 36480 .

Andersen, L. L., Andersen, C. H., Mortensen, O. S., Poulsen, O. M., Bjørnlund, I. B. T. \& Zebis, M. K. (2010). Muscle activation and perceived loading during rehabilitation exercises: comparison of dumbbells and elastic resistance. Physical Therapy, 90(4), 538-549. https://doi: 10.2522/ptj.20090167.

Arnold, B. L. \& Schmitz, R. J. (1998). Examination of balance measures produced by the Biodex Stability System. Journal of Athletic Training, 33(4), 323-327.

Aydin, T., Yildiz, Y., Yildiz, C., Atesalp, S. \& Kalyon, T. A. (2002). Proprioception of the ankle: a comparison between female teenaged gymnasts and controls. Foot \& Ankle International, 23(2), 123-129. https://doi: $10.1177 / 107110070202300208$.

Baker, A. G., Webright, W. G. \& Perrin, D. H. (1998). Effect of a "T-band" kick training protocol on postural sway. Journal of Sport Rehabilitation, 7(2), 122-127. https://doi.org/10.1123/jsr.7.2.122

Baltaci, G., Ergur, N. ve Bayrakci Tunay, V. (2016). Spor yaralanmalarinda egzersiz tedavisi. Ankara. Hipokrat Kitapevi.

Cachupe, W. J., Shifflett, B., Kahanov, L. \& Wughalter, E. H. (2001). Reliability of Biodex Balance System measures. Measurement in Physical Education and Exercise Science, 5(2), 97-108. http//doi:org/10.1207/S15327841MPEE0502_3

Colado, J. C., Garcia-Masso, X., Triplett, T. N., Flandez, J., Borreani, S. \& Tella, V. (2012). Concurrent validation of the OMNI-resistance exercise scale of perceived exertion with Thera-band resistance bands. The Journal of Strength \& Conditioning Research, 26(11), 3018-3024. http//doi: 10.1519/JSC.0b013e318245c0c9.

Colado, J. C. \& Triplett, N. T. (2008). Effects of a short-term resistance program using elastic bands versus weight machines for sedentary middle-aged women. The Journal of Strength \& Conditioning Research, 22(5), 1441-1448. http//doi: 10.1519/JSC.0b013e31817ae67a.

Colado, J. C., Triplett, N. T., Tella, V., Saucedo, P. \& Abellán, J. (2009). Effects of aquatic resistance training on health and fitness in postmenopausal women. European Journal of Applied Physiology, 106(1), 113-122. http//doi: 10.1007/s00421-009-0996-7.

Durnin, J. V. \& Womersley, J. (1974). Body fat assessed from total body density and its estimation from skinfold thickness: measurements on 481 men and women aged from 16 to 72 years. British Journal of Nutrition, 32(1), 77-97. http//doi: 10.1079/bjn19740060.

Egana, M., Reilly, H. \& Green, S. (2010). Effect of elastic-band-based resistance training on leg blood flow in elderly women. Applied Physiology, Nutrition, and Metabolism, 35(6), 763-772. http//doi: org/10.1139/H10-071.

Erkmen, N., Suveren, S., Göktepe, A. \& Yazıcıglu, K. (2007). The comparison of balance performance of the athletes who are in different branches. Sportmetre, 5, 115-122.

Fisher, J., Steele, J., Bruce-Low, S. \& Smith, D. (2011). Evidence based resistance training recommendations. Medicina Sportiva, 15(3), 147-162. http//doi:10.5604/17342260.1081302

Han, K., Ricard, M. D. \& Fellingham, G. W. (2009). Effects of a 4-week exercise program on balance using elastic tubing as a perturbation force for individuals with a history of ankle sprains. Journal of Orthopaedic \& Sports Physical Therapy, 39(4), 246-255. http//doi: 10.2519/jospt.2009.2958.

Holviala, J., Häkkinen, A., Alen, M., Sallinen, J., Kraemer, W. \& Häkkinen, K. (2014). Effects of prolonged and maintenance strength training on force production, walking, and balance in aging women and men. Scandinavian Journal of Medicine \& Science in Sports, 24(1), 224-233. http//doi: 10.1111/j.16000838.2012.01470.x.

Hostler, D., Schwirian, C. I., Campos, G., Toma, K., Crill, M. T., Hagerman, G. R., Hagerman, F. C. \& Staron, R. S. (2001). Skeletal muscle adaptations in elastic resistance-trained young men and women. European 
Kocaoğlu, Y. \& Erkmen, N. (2021). The effect of elastic resistance band training on postural control and body composition in sedentary women. Journal of Sport Sciences Researches, 6(1), 233-245.

Journal of Applied Physiology, 86(2), 112-118. http//doi:10.1007/s004210100495.

Jakobsen, M. D., Sundstrup, E., Andersen, C. H., Aagaard, P. \& Andersen, L. L. (2013). Muscle activity during leg strengthening exercise using free weights and elastic resistance: effects of ballistic vs controlled contractions. Human Movement Science, 32(1), 65-78. http//doi:10.1016/j.humov.2012.07.002.

Kaminski, T. W. \& Hartsell, H. D. (2002). Factors contributing to chronic ankle instability: a strength perspective. Journal of Athletic Training, 37(4), 394-405.

Kılınç, H., İrez, G. \& Saygın, Ö. (2014). The Effects of Swisball and Theraband exercise on quality of life and some physical parameters of people aged 65 years and over. International Journal of Human Sciences, 11(2), 668-680. http//doi: 10.14687/ijhs.v11i2.305.

Kitamura, F. \& Matsunaga, K. (1990). Field dependence and body balance. Perceptual and Motor Skills, 71(3), 723-734. http//doi:10.2466/pms.1990.71.3.723.

Kraemer, W.J., Keuning, M., Ratamess, N.A., Volek, J.S., Mccormick, M., Bush, J.A. \& Newton, R.U. (2001). Resistance training combined with bench-step aerobics enhances women's health profile. Medicine \& Science in Sports \& Exercise, 33(2), 259-269. http//doi:10.1097/00005768-200102000-00015.

Kwon, H. R., Han, K. A., Ku, Y. H., Ahn, H. J., Koo, B.K., Kim, H. C. \& Min, K. W. (2010). The effects of resistance training on muscle and body fat mass and muscle strength in type 2 diabetic women. Korean Diabetes Journal, 34(2), 101-110. http//doi: 10.4093/kdj.2010.34.2.101.

LeCheminant, J., Hinman, T., Pratt, K., Earl, N., Bailey, B., Thackeray, R. \& Tucker, L. (2014). Effect of resistance training on body composition, self-efficacy, depression, and activity in postpartum women. Scandinavian Journal of Medicine \& Science in Sports, 24(2), 414-421. http//doi: 10.1111/j.16000838.2012.01490.x.

LeMura, L. M., von Duvillard, S. P., Andreacci, J., Klebez, J. M., Chelland, S. A. \& Russo, J. (2000). Lipid and lipoprotein profiles, cardiovascular fitness, body composition, and diet during and after resistance, aerobic and combination training in young women. European Journal of Applied Physiology, 82(5-6), 451-458. http//doi: 10.1007/s004210000234.

Lubans, D. R., Sheaman, C. \& Callister, R. (2010). Exercise adherence and intervention effects of two schoolbased resistance training programs for adolescents. Preventive Medicine, 50(1-2), 56-62. http//doi: 10.1016/j.ypmed.2009.12.003.

Marion, T. \& Tony, E. (1997). Human movement: An introductory text. New York, USA: Churchill livingstone,

McLeod, B. \& Hansen, E. (1989). Effects of the eyerobics visual skills training program on static balance performance of male and female subjects. Perceptual and Motor Skills, 69(3), 1123-1126. https://doi.org/10.1177/00315125890693-211.

Page, P. \& Ellenbecker, T. S. (2019). Strength band training. Champaign, IL: Human Kinetics Publishers.

Patterson, R. M., Stegink Jansen, C. W., Hogan, H. A. \& Nassif, M. D. (2001). Material properties of thera-band tubing. Physical Therapy, 81(8), 1437-1445. https://doi.org/10.1093/ptj/81.8.1437.

Prabhakaran, B., Dowling, E. A., Branch, J. D., Swain, D. P. \& Leutholtz, B. C. (1999). Effect of 14 weeks of resistance training on lipid profile and body fat percentage in premenopausal women. British Journal of Sports Medicine, 33(3), 190-195. https://doi: 10.1136/bjsm.33.3.190.

Rakıcıŏ̆lu, N. (2008). Yaşlıda şişmanlık. Ankara: Sağlık Bakanlığı Yayınları (729).

Ratamess, N. (2011). ACSM's foundations of strength training and conditioning. London: Lippincott Williams \& Wilkins.

Rogers, M. E., Sherwood, H. S., Rogers, N. L. \& Bohlken, R. M. (2002). Effects of dumbbell and elastic band training on physical function in older inner-city African-American women. Women \& Health, 36(4), 3341. https://doi: 10.1300/J013v36n04_03.

Shumway-Cook, A. \& Woollacott, M. (2001). Motor control: Theory and practical applications. Philadelphia: Lippincott Williams \& Wilkins. 
Siri, W. E. (1956). The gross composition of the body. Adv Biol Med Phys, 4, 239-80. https://doi: 10.1016/b9781-4832-3110-5.50011-x.

Teasdale, N., Bard, C., LaRue, J. \& Fleury, M. (1993). On the cognitive penetrability of posture control. Experimental Aging Research, 19(1), 1-13. https://doi.org/10.1080/03610739308253919.

Thera-Band. (2012). Resistance band \& tubing instruction manual. USA: APTA

Ünlüsoy, D., Aydoğ, E., Tuncay, R., Eryüksel, R., Ünlüsoy, İ. \& Çakc1, A. (2011). Postural balance in women with osteoporosis and effective factors. Turkish Journal of Osteoporosis, 17(2), 37-43.

Except where otherwise noted, this paper is licensed under a Creative Commons Attribution 4.0 International license. 